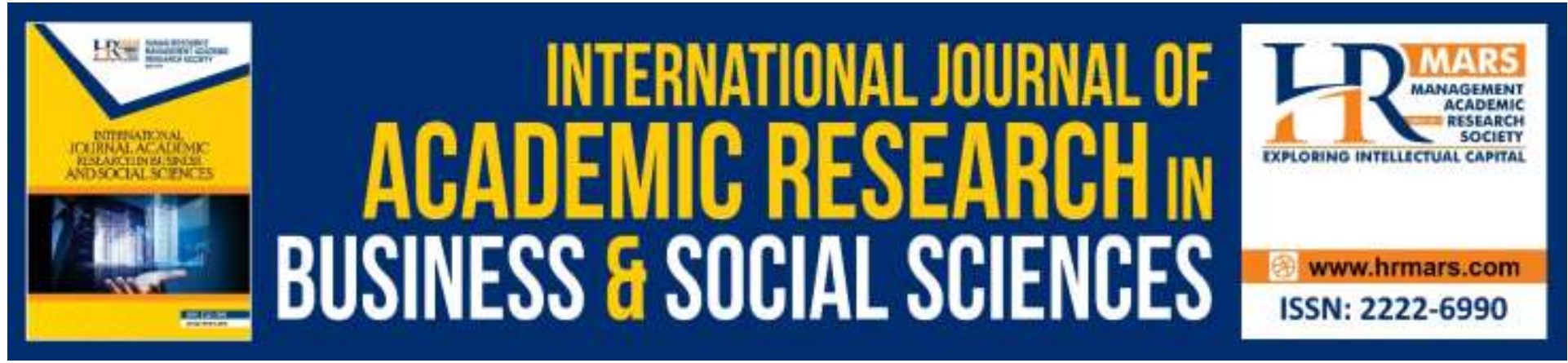

\title{
Fostering Intellectual Excitement Questionnaire: The Development and Validation
}

\author{
Rosdy Wahid, Eng Tek Ong, Muhammad Ikhwan Mat Saat
}

To Link this Article: http://dx.doi.org/10.6007/IJARBSS/v9-i7/6183

DOI: $10.6007 /$ IJARBSS/v9-i7/6183

Received: 04 May 2019, Revised: 16 June 2019, Accepted: 26 June 2019

Published Online: 24 July 2019

In-Text Citation: (Wahid, Ong, \& Saat, 2019)

To Cite this Article: Wahid, R., Ong, E. T., \& Saat, M. I. M. (2019). Fostering Intellectual Excitement Questionnaire: The Development and Validation. International Journal of Academic Research in Business and Social Sciences, 9(7), 832-842.

\section{Copyright: (C) 2019 The Author(s)}

Published by Human Resource Management Academic Research Society (www.hrmars.com)

This article is published under the Creative Commons Attribution (CC BY 4.0) license. Anyone may reproduce, distribute, translate and create derivative works of this article (for both commercial and non-commercial purposes), subject to full attribution to the original publication and authors. The full terms of this license may be seen at: http://creativecommons.org/licences/by/4.0/legalcode

\section{Vol. 9, No. 7, 2019, Pg. 832 - 842}

Full Terms \& Conditions of access and use can be found at http://hrmars.com/index.php/pages/detail/publication-ethics 


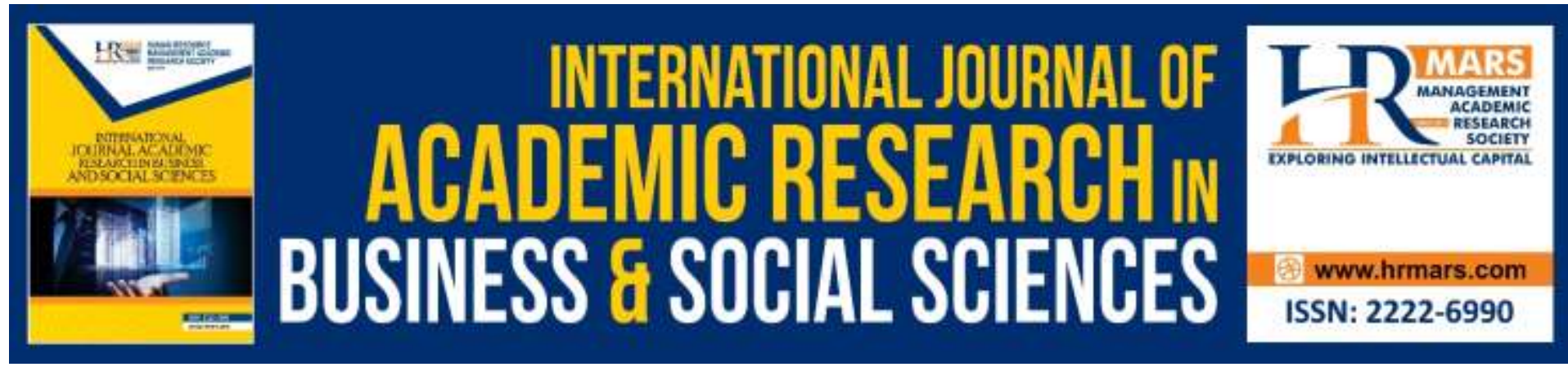

\title{
Fostering Intellectual Excitement Questionnaire: The Development and Validation
}

\author{
Rosdy Wahid, Eng Tek Ong, Muhammad Ikhwan Mat Saat \\ Faculty of Human Development, Sultan Idris Education University, Tanjong Malim, Malaysia
}

\begin{abstract}
This paper reports the findings on the development and validation of the Fostering Intellectual Excitement (IE) Questionnaire amongst the student teachers. Initially, 16 items which portray the construct of Fostering IE were generated and subsequently administered to a group of 248 teachers. Analyzing the dataset using the Exploratory Factor Analysis (EFA) indicates that, while all the 16 items of IE were retained, they were nevertheless clustered into 4 sub-constructs, labelled as Group Discussion (GD), Critical Thinking (CT), Evaluate Peer's Work (EW) and Knowledge Transfer (KT) respectively. This 4-sub-construct Fostering IE Questionnaire was again administered to 458 in-service teachers and the dataset were analyzed by means of the Confirmatory Factor Analysis (CFA) whereby each measurement model was tested to see the relationship of each sub-construct (or latent variable) with its measures. The finding shows that each of the four sub-constructs of the IE has the sufficient validity and model fit. Consequently, a valid and reliable Fostering Intellectual Excitement Questionnaire with 4 sub-constructs, namely GD, CT, EW and KT, were generated and validated which teacher educators could capitalize on to gauge the extent such a teaching behavior has been enacted in their respective classroom.
\end{abstract}

Keywords: Measurement Model, Intellectual Excitement, Group Discussion, Critical Thinking, Evaluate Peer's work, Knowledge Transfer

\section{Introduction}

In the current trend where student-centered approach is under the spotlight, learning has to be meaningful and interesting. Student needs to be actively involved in their learning. The conviction of teaching is about "transmitting knowledge" needs to be diverted to teaching is facilitating or assisting students in their learning exploration. This is to be aligned with the definition of quality teaching by few scholars, for example Darling-Hammond and Bransford (2005) and Henard and Leprince-Ringuet (2008) who claimed that learning is about what students have achieved at the end of the day. In short, these scholars defined quality teaching as facilitating students and providing opportunities to the students to explore rather than to just listen and absorb information given by the teacher. The setting of teaching should also boost the student intellect level so that learning can be meaningful. In preparing teachers for the future, teacher educators need to ensure intellectual excitement is imbedded in their teaching. This is crucial because whatever experience vicariously gained by student teachers 
in a teacher education institution will somehow influence the way in which they teach in school (Jefferson, 2009).

\section{Literature Review}

Fostering intellectual excitement is one of the elements needed in aligning teacher education to the characteristics of a quality teacher. Perkins, Schenk, Sh, and Vrungos (1995) defined the intellectual excitement as a process of bringing the students to the ambience where the critical thinking as well as the problem-solving take place. The review of the literature indicates that the training a teacher gets will affect the way he/she teaches in school (DarlingHammond, 2006). Therefore, it is crucial to provide a surrounding that excites a student teacher's intellect in teacher education institution with the hope that he/she will, in turn, provide similar intellectual excitement in his/her teaching. Teacher educators need to gear teaching towards boosting student teachers' intellectuality by inculcating thinking in the classroom activities. By eliciting a yes or no, or right or wrong response from the student teachers, teacher educators are not promoting thinking. Instead, the dichotomous response should go beyond student teachers' intellectual capacity such as giving ideas, critiquing, and evaluating.

Based on the ethnographic analysis of over 500 nominations for teaching awards, McCaslin and Lowman (1995) found that fostering intellectual excitement has a larger effect on student learning. This finding corresponds to other literature that suggested a few domains that gear towards fostering student teachers' intellectual excitement. One of the domains is that of group discussion in which teacher educators advocate the use of argumentation that requires students to justify their ideas with facts and this obviously leads to the discussion with regard to challenging student teachers' intellect (Caires, Almeida, \& Vieira, 2012; Kroll, 2004). Group discussion triggers not only the presenter's level of intellect, but also the levels of intellect of other student teachers who ask questions (Samples \& Copeland, 2013).

A quasi experimental design study by Crowe, Silva, and Ceresola (2015) has discovered that students need to use their level of intellect in order to comment on their peers. Therefore, students should be given the opportunity to evaluate and comment on their peers' work, giving the necessary and useful suggestions. Samples and Copeland (2013), for example, proposed that teachers should encourage students to react, argue and challenge their peers' presentation. This will trigger and spark the intellectuality at both sides, namely the presenter and the audience. The discussion and argument amongst student teachers are one of the ways of transferring their knowledge amongst each other (Samples \& Copeland, 2013). Studies have shown that classroom setting which advocates the knowledge transfer during the group discussion will also boost students' intellect (Crowe et al., 2015). All these four domains that were found in the literature support the activities that will trigger a student teacher's level of intellect and should be considered well-ahead in the planning for teaching student teachers.

\section{Purpose of the Study}

This purpose of this study was two-fold. Firstly, it aimed to develop and validate a questionnaire on Intellectual Excitement, and secondly, to confirm the dimensions (or subconstructs) that were derived from the earlier construct of fostering Intellectual Excitement 
which the review of the literature found it to be an important aspect that needs to be inculcated by teacher education institutions.

\section{Methodology}

\section{Research Design}

The research design employed was that of two phases. The first phase involved the development and validation of a questionnaire on Intellectual Excitement, while the second phase involved the confirmation by means of confirmatory factor analysis for each of the subconstructed emerged in the first phase.

\section{Sample}

Given the objectives of the study, two stages of sampling were involved. Firstly, in exploring the concept of Intellectual Excitement, which is portrayed by 13 items, 248 teachers were selected as respondents. Gorush (1983) and Comrey and Lee (1973) recommended that a sample size within the range between 100 and 250 is good to run an Exploratory Factor Analysis (EFA). Secondly, in confirming the sub-constructs of Intellectual Excitement that were emerged in the earlier phase, 458 teachers were involved as the respondents. The samples were selected by following the Krejcie and Morgan's (1970) Table for determining the samples size. The initial sample size selected was 350. However, since this involves a survey of the respondents, the response rates are typically predicted below hundred percent (Bartlett, 2005), and thus, $40 \%$ were added to the earlier sample size of 350 as suggested by Salkind (1997) to avoid the low return of the survey. Accordingly, the drawn sample size from the population was 490 teachers to which the questionnaire was administered. However, only 458 respondents returned their questionnaires.

\section{Instrument}

In Phase 1, the Intellectual Excitement Questionnaire was developed by generating a total of 16 items which purportedly represent or portray the concept of Intellectual Excitement. The items were shown in Table 1. 
Table 1. 16-item Questionnaire

\begin{tabular}{|c|c|}
\hline Sub-construct & Items \\
\hline $\begin{array}{c}1 \\
\text { Group Discussion }\end{array}$ & $\begin{array}{l}\text { 1. having student teachers complete a problem-solving } \\
\text { game in class. } \\
\text { 2. assigning small group discussions. } \\
\text { 3. having student teachers do small group presentations } \\
\text { through plays or panel discussions. } \\
\text { 4. encouraging student teachers to debate on issues } \\
\text { related to the topics covered in the course. } \\
\text { 5. using role-plays and simulations. } \\
\text { 6. assigning small research project. }\end{array}$ \\
\hline
\end{tabular}

\begin{tabular}{|c|c|}
\hline $\begin{array}{c}2 \\
\text { Critical Thinking }\end{array}$ & $\begin{array}{l}\text { 7. having student teachers to present their work in class. } \\
\text { 8. encouraging student teachers to challenge ideas of } \\
\text { their classmates or other people. } \\
\text { 9. having student teachers to analyse and discuss real- } \\
\text { life situations related to the topics covered in the } \\
\text { course. } \\
\text { 10. having student teachers to write critical reviews about } \\
\text { a reading text. }\end{array}$ \\
\hline $\begin{array}{l}\quad 3 \\
\text { Evaluate Peer's } \\
\text { Work }\end{array}$ & $\begin{array}{l}\text { 11. having student teachers to critically evaluate the work } \\
\text { of their peers. } \\
\text { 12. using real life situation as examples. } \\
\text { 13. having student teachers compare theories relevant to } \\
\text { the course. }\end{array}$ \\
\hline \begin{tabular}{l}
\multicolumn{1}{c}{4} \\
Knowledge \\
Transfer
\end{tabular} & $\begin{array}{l}\text { 14. asking questions that require higher order thinking } \\
\text { (e.g. applying, analysing, synthesising, creating, } \\
\text { evaluating, reasoning). } \\
\text { 15. having student teachers involve in multidisciplinary } \\
\text { project teams and /or professional practice setting. } \\
\text { 16. having student teachers engage in knowledge transfer } \\
\text { activities in communities, professions and/or } \\
\text { industries. }\end{array}$ \\
\hline
\end{tabular}

All the items use the five-point Likert scale format. The scale ranges from 1 to 5 points: $1=$ Not at all important, 2=Slightly important, 3=Moderately important, 4=Very important, $5=$ Extremely important. Given that all the 16 items were retained in Phase 1, these are items were reused for Phase 2. In other words, the 16-item Intellectual Excitement Questionnaire was again and administered, but to group of different respondents. 


\section{Data Analysis Procedure}

In Phase 1, the dataset collected were analysed using Exploratory Factor Analysis with varimax rotation. In Phase 2, the dataset collected were analysed by means of Confirmatory Factor Analysis (CFA). In Phase 1, SPSS 21 was used while in Phase 2, AMOS 25 was employed.

\section{Findings}

The findings are presented in two phases. Phase 1 is the validation of the Intellectual Excitement Questionnaire, while Phase 2, the confirmation of the sub-constructs of the Intellectual Excitement Questionnaire.

\section{Phase 1}

Findings of the EFA shows the KMO for the IE is .907 indicated that the IE items were factorable and sufficient to conduct a factor analysis. This is according to Cerny and Kaiser (1977) stated that adequate value for KMO test is between 0.8 to 1. The Bartlett's Test for the construct IE is significant $(p<0.05)$, indicating that the correlation between the items are adequate to conduct a factor analysis. The results of KMO and Bartlet's Test for IE are shown in Table 2.

Table 2. The KMO and Bartlet's Test for IE

\begin{tabular}{llr}
\hline Kaiser-Meyer-Olkin Measure of Sampling Adequacy. & .907 \\
& Approx. Chi-Square & 1731.827 \\
Bartlett's Test of Sphericity & $\mathrm{df}$ & 120 \\
& Sig. & .000 \\
\hline
\end{tabular}

When subjected to principal components factor analysis, 16 factors were produced. This was expected because in every factor analysis, there are the same number of factors as there are variables. Hence, a factor rotation was used, and more specifically, the varimax rotation. The results of the rotated component matrix are given in Table 3. The factor loading for each of the items for IE construct is greater than .40 which is considered as fair according to Tabachnick \& Fidell (2001). As shown in Table 3, the items were clustered into four subconstructs based on the factor loading values. 
Table 3. Rotated Component Matrix

\begin{tabular}{|c|c|c|c|c|}
\hline Constructs & 1 & 2 & 3 & 4 \\
\hline Q1 Intellectual excitement & .748 & & & \\
\hline Q2 Intellectual excitement & .774 & & & \\
\hline Q3 Intellectual excitement & .806 & & & \\
\hline Q4 Intellectual excitement & .678 & & & \\
\hline Q5 Intellectual excitement & .649 & & & \\
\hline Q9 Intellectual excitement & .431 & & & \\
\hline Q6 Intellectual excitement & & .455 & & \\
\hline Q8 Intellectual excitement & & .496 & & \\
\hline Q11 Intellectual excitement & & .580 & & \\
\hline Q13 Intellectual excitement & & .792 & & \\
\hline Q7 Intellectual excitement & & & .504 & \\
\hline Q10 Intellectual excitement & & & .569 & \\
\hline Q12 Intellectual excitement & & & .876 & \\
\hline Q14 Intellectual excitement & & & & .602 \\
\hline Q15 Intellectual excitement & & & & .458 \\
\hline Q16 Intellectual excitement & & & & .838 \\
\hline
\end{tabular}

Each of the sub-constructs emerged was named according to theme and frequency of the words and phrases occurred in the items for each construct. The first sub-constructs with 6 items was named Group Discussion (GD), while the second sub-construct with 4 items was labelled as Critical Thinking (CT). Meanwhile, the third sub-construct with 3 items was labelled as Evaluate Peer's Work (EW) while the fourth sub-construct with 3 items was labelled as Knowledge Transfer (KT). Therefore, in Phase 1, a valid and reliable 4-factor Intellectual Excitement was produced.

\section{Phase 2}

The findings of the measurement model for each of the sub-construct are presented in Table 3. According to Fornell \& Larcker (1981) and Bagozzi \& Yi (1988) the construct is valid when it has achieved an acceptable value when Outer Factors greater than 0.5, Composite Reliability (CR) greater than 0.6 and the Average Variance Extract (AVE) greater than 0.5. Findings of this study have shown that GD has achieved all the acceptable values meanwhile the AVE for CT, EW and KT have achieved lower than acceptable value 0.5 . The value of 0.4 lesser than 0.5 is acceptable if the CR is higher than 0.6 (Fornell and David, 1981). Table 3 shows the acceptable values of the sub-constructs that emerged from the IE of this study. 
Table 3. The Acceptable Values for the Sub-constructs for IE

\begin{tabular}{|c|c|c|c|c|c|}
\hline Variables & Item & $\begin{array}{l}\text { Outer Loading } \\
\quad(>0.5)\end{array}$ & $\begin{array}{c}C . R \\
(\geq 0.6)\end{array}$ & $\begin{array}{c}\text { AVE } \\
(\geq 0.5)\end{array}$ & $\begin{array}{c}\text { AVE } \\
\text { SQUARED }\end{array}$ \\
\hline $\begin{array}{c}1 \\
\text { Group } \\
\text { Discussion (GD) }\end{array}$ & $\begin{array}{l}\text { e1 } \\
\text { e2 } \\
\text { e3 } \\
\text { e4 } \\
\text { e5 } \\
\text { e6 }\end{array}$ & $\begin{array}{l}.584 \\
.789 \\
.772 \\
.742 \\
.675 \\
.597\end{array}$ & 0.848 & 0.847 & 0.698 \\
\hline $\begin{array}{c}2 \\
\text { Critical } \\
\text { Thinking }(C T)\end{array}$ & $\begin{array}{c}\text { e7 } \\
\text { e8 } \\
\text { e9 } \\
\text { e10 }\end{array}$ & $\begin{array}{l}.742 \\
.544 \\
.573 \\
.500\end{array}$ & 0.682 & 0.453 & 0.595 \\
\hline $\begin{array}{c}3 \\
\text { Evaluate Peer's } \\
\text { Work (EW) }\end{array}$ & $\begin{array}{l}\text { e11 } \\
\text { e12 } \\
\text { e13 }\end{array}$ & $\begin{array}{l}.662 \\
.685 \\
.516\end{array}$ & 0.618 & 0.460 & 0.600 \\
\hline $\begin{array}{c}4 \\
\text { Knowledge } \\
\text { Transfer (KT) }\end{array}$ & $\begin{array}{l}\text { e14 } \\
\text { e15 } \\
\text { e16 }\end{array}$ & $\begin{array}{l}.688 \\
.632 \\
.529\end{array}$ & 0.649 & 0.483 & 0.620 \\
\hline
\end{tabular}

The Measurement Model for IE shows a validity and is fit when the value for the goodness of fit RMSEA = .09. This is in accordance to Hair, William \& Babin (2011) and Kline (2011) that the model is fit when RMSEA $\leq 0.08$ and MacCallum (1996) that the RMSEA range from 0.08 to 0.10 is consider a mediocre fit. The CFI for IE is .089 according to Kline (2011) the CFI $\geq 0.90$ is an acceptable value for model fit. Whereby the Chi-square/df $=95$ have shown a nonsignificant value is less than .05 but Chi-square is not the only way to determine if the model is fit (Byrne, 2010) and (Kline, 2011). In the case of bigger samples size that more than 200 Chi-square is not suitable to be used to measure if the model is fit (Zainudin Awang, 2015). Figure 1 shows the Measurement Model of the IE. 
Figure 1. The Measurement Model of Intellectual Excitement (IE)

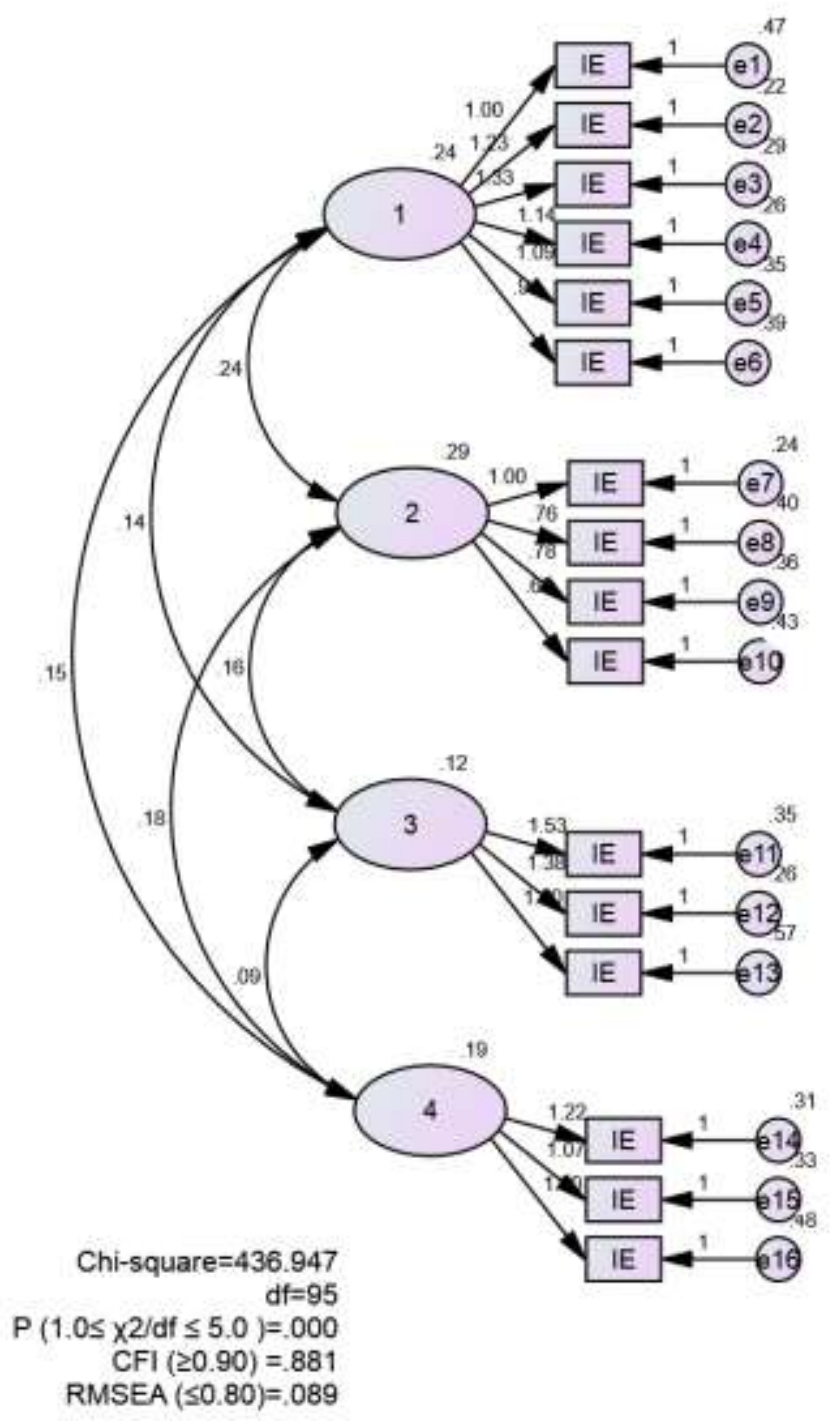

\section{Conclusion}

Four sub-constructs emerged from EFA of the study were further validated by employing the CFA in Measurement Model and it has a validity and fit the data study if it has achieved a goodness of fit as suggested by Hair, Black, Babin and Anderson (2014) that the model is fit by utilizing at least three model fit namely absolute indices, incremental fit indices and parsimonious fit indices. The psychometric findings were supported by the literature (see Perkins, Schenk, Sh, and Vrungos, 1995); Caires, Almeida and Vieira (2012); Kroll (2004); and Silva and Ceresola (2015)) that suggested the four domains of intellectual excitement as a finding in their study. Therefore, teacher educators need to integrate all 4 domains namely Group Discussion, Critical Thinking, Evaluate Peer's Work and Knowledge transfer in their teaching and learning activity in order to foster intellectual excitement amongst student teacher. 


\section{Acknowledgement}

We acknowledge with great appreciation to the Niche Grant Scheme (Coded: NRGS/KPT 20140001-107-82-2) for granting this project and we would like to express our gratitude to all the team members of group 2 (Teaching and Learning) for their unwavering support throughout the study.

\section{Corresponding Author}

Rosdy Bin Wahid

Faculty of Human Development

Sultan Idris Education University

Malaysia

Email: tobezuka@gmail.com

\section{References}

Atwood, S., Turnbull, W., \& Carpendale, J. I. M. (2010). The construction of knowledge in classroom talk. Journal of the Learning Sciences.

Atwood, S., Turnbull, W., \& Jeremy, I. M. (2010). Journal of the Learning The Construction of Knowledge in Classroom Talk. Journal of the Learning Sciences.

Bagozzi, R. P., \& Yi, Y. (1988). On the evaluation of structural equation models. Journal of the academy of marketing science, 16(1), 74-94.

Bartlett, K. R. (2005). Survey research in organizations. Research in Organizations: Foundations and Methods of Inquiry, 97-113.

Barbara, B. M. (2010). Structural Equation Modeling with AMOS (Second Edi). Routledge New York London.

Caires, S., Almeida, L., \& Vieira, D. (2012). Becoming a teacher: Student teachers' experiences and perceptions about teaching practice. European Journal of Teacher Education, 35(2), 163-178. http://doi.org/10.1080/02619768.2011.643395

Cerny, B. A., \& Kaiser, H. F. (1977). A study of a measure of sampling adequacy for factoranalytic correlation matrices. Multivariate behavioral research, 12(1), 43-47.

Comrey, A. L., \& Lee, H. B. (1973).A first course in factor analysis. New York: Academic Press.

Crowe, J. A., Silva, T., \& Ceresola, R. (2015). The Effect of Peer Review on Student Learning Outcomes in a Research Methods Course. Teaching Sociology, 43(3), 201-213.

Darling-Hammond, L., \& Bransford, J. (2005). Preparing Teachers for a Changing World : What Teachers Should Learn and Be Able to Do. The Jossey-Bass Education Series. Wiley. http://doi.org/10.5860/CHOICE.43-1083

Darling-Hammond, L. (2006a). Constructing 21st-century teacher education. Journal of Teacher Education, 57(3), 300-314.

Darling-Hammond, L. (2006b). Powerful Teacher Education: Lessons from Exemplary Programs. The JosseyBass Education Series.

Henard, F., and Leprince-Ringuet, S. (2008). The path to quality teaching in Higher Education. Programme Institutional Management for Higher Education, (October 2007), 1-50. Retrieved from http://www.oecd.org/dataoecd/10/60/41692318.pdf

Fornell, C. and David, F. L. (1981). Evaluating structural equation models with unobservable variables and measurement error. Journal of marketing research, 39-50. 
Jefferson, A. L. (2009). Teacher training: what's needed. Journal of Further and Higher Education, 33(3), 281-288. http://doi.org/10.1080/03098770903026198

Gorsuch, R. L. (1983). Factor Analysis (2nd ed.). Hillsdale, NJ: Lawrence Erlbaum Associates.

Hair, Joseph F., William, C. B., Babin, B. J. Rolph, E. A. (2011). Multivariate Analysis (seventh ed). New Jersey, Prentice Hall.

Kline, R. B. (2011). Principles and Practice of Structural Equation Modeling. The Guilford Press New York London.

Kroll, L. R. (2004). Constructing constructivism: How student-teachers construct ideas of development, knowledge, learning, and teaching. Teachers and Teaching: Theory and Practice, 10(2), 199-221. http://doi.org/10.1080/1354060042000188035

MacCallum, R. C., Browne, M. W., and Sugawara, H. M. (1996), "Power Analysis and Determination of Sample Size for Covariance Structure Modeling," Psychological Methods, 1 (2), 130-49.

McCaslin, W. J., \& Lowman, J. (1995). Mastering the Techniques of Teaching. Teaching Sociology. http://doi.org/10.2307/1318070

Perkins, D., Schenk, T. A., Sh, L. S., \& Vrungos, C. (1995). Effects Of Rapport, Intellectual Excitement, And Learning O N Students' Perceived Ratings Of College Instructors '. Psychological Reports, 76, 627-635.

Ratnavadivel, N., Hoon, C. L., Salih, M., \& Low, J. (2014). Curriculum framework for preparing quality teachers for the future : Developing guiding principles, 4(2), 32-44.

Salkind, N. J. (1997). Exploring research (3rd ed.). Upper Saddle River, NJ: Prentice Hall.

Samples, J. W. \& Copeland, S. E. (2013). The Universality of Good Teaching: A Study of Descriptors Across Disciplines. International Journal of Teaching \& Learning in Higher Education, 25(2), 176-188.

Tabachnick, B. G., \& Fidell, L. S. (2001). Using Multivariate Analysis. Northridge: California State University, Harper Collins College Publishers.

Wasley, P. (2006). Underrepresented students benefit most from "engagement" (Vol. 53).

Awang, Z. (2015). SEM made simple: a gentle approach to learning structural equation modeling. MPWS Rich Publication. 